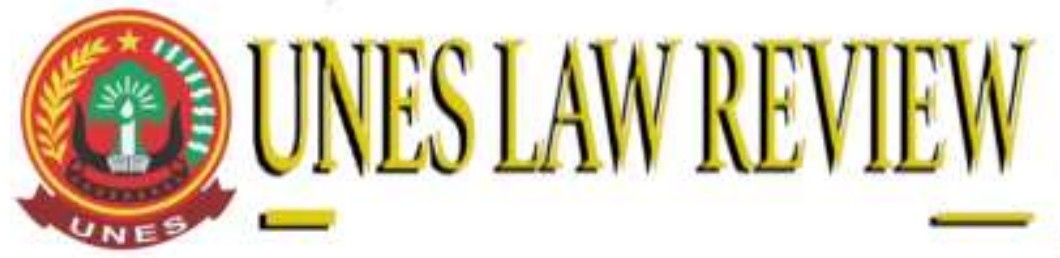

$+6282287504359$

$+6282287504359$

https://review-unes.com/

uneslawreview@gmail.com

DOI: https://doi.org/10.31933/unesrev.v3i3

Diterima: 24/03/2021, Diperbaiki: 21/05/2021, Diterbitkan: 23/04/2021

\title{
PERUBAHAN AKTA PERSEROAN TERBATAS OLEH NOTARIS DALAM RANGKA PENAWARAN UMUM (GO PUBLIC)
}

\section{Yogi Agus Saputra}

Program Pasca Sarjana Magister Kenotariatan, Fakultas Hukum, Universitas Andalas, Padang Email: delvyrahmadhini@gmail.com

Corresponding Author: Yogi

\section{ABSTRACT}

Along with economic development, companies both small, medium and large scale always try to develop their business, one of which is how to meet capital needs. As for how to meet these capital needs by investing. Types and forms of investment are divided into two, namely: direct investment and indirect investment. Notary is one of the capital market supporting institutions where the notary is a general official who makes the deed of Amendment to the Articles of Association including Underwriting Agreement, Inter-Underwriter Agreement, Share Administration Management Agreement, Warrant Issuance Statement, Share Administration Management Agreement and other necessary agreements. To be able to carry out activities in the capital market sector, it must first be registered with the Financial Services Authority. The notary profession as one of the capital market supporting professions which will be the object of the author's research. The problems are: 1. How is the substance change in the Articles of Association of a Limited Liability Company in the context of a Public Offering (Go Public)? 2. What is the responsibility of the Notary on the deeds he made in the context of a public offering (going public)? The method used in this research is an empirical juridical approach, namely approaching the problem through research by looking at the norms or legal provisions that apply. Based on research results. The substance of the articles to be disposed of in the Articles of Association must be in line with the assisting regulations of the Capital Market Law, the Keauang Service Authority, and the regulations of the Indonesia Stock Exchange. The Capital Market Law requires Notaries to be accountable materially and formally for deeds made in the framework of a public offering (going public), for this reason the notary must conduct in-depth research (due ligence) before the deeds are drawn up.

Keywords: Effective Limited liability company, Go Public, Notary 


\section{ABSTRAK}

Seiring dengan perkembangan perekonomian, perusahaan baik berskala kecil, menengah maupun besar selalu berusaha untuk mengembangkan usahanya, salah satu diantaranya yaitu bagaimana memenuhi kebutuhan modal. Adapun cara memenuhi kebutuhan modal tersebut dengan cara melakukan penanaman modal. Jenis dan bentuk penanaman modal terbagi menjadi dua, yaitu: penanaman modal lansung (direct Invesment) dan penanaman modal tidak lansung (Indirect Invesment). Notaris merupakan salah satu lembaga penunjang pasar modal dimana notaris merupakan pejabat umum yang berwenang membuat akta Perubahan Anggaran Dasar termasuk pembuatan Perjanjian Penjaminan Emisi Efek, Perjanjian Antar Penjamin Emisi Efek, Perjanjian Pengelolaan Adminitrasi Saham, Pernyataan Penerbitan Waran, Perjanjian Pengelolaan Adminitrasi Saham dan perjanjian lain yang diperlukan. Untuk dapat melakukan kegiatan di bidang pasar modal, notaris wajib terlebih dahulu terdaftar di Otoritas Jasa Keuangan. Profesi notaris sebagai salah satu profesi penunjang pasar modal yang akan menjadi objek penelitian penulis. Adapun permasalahannya yaitu: 1.Bagaimana Perubahan Substansi Anggaran Dasar Perseroan Terbatas dalam Rangka Penawaran Umum (Go Public)? 2. Bagaimana tanggung jawab bagi Notaris terhadap akta-akta yang dibuatnya dalam rangka penawaran umum (go public)? Metode yang digunakan dalam penelitian ini adalah pendekatan yuridis empiris, yaitu pendekatan masalah melalui penelitian dengan melihat norma-norma atau ketentuan hukum yang berlaku. Berdasarkan hasil penelitian. substansi dari pasal-pasal yang akan dituangkan ke dalam Anggaran Dasar tersebut, haruslah sejalan dengan peraturan yang mengatur yaitu UndangUndang Pasar Modal, Peraturan Otoritas Jasa Keauang, dan peratura Bursa Efek Indonesia.Undang-Undang Pasar Modal mewajibkan Notaris bertanggung jawab secara materil dan formil terhadap akta-akta yang dibuatnya dalam rangka penawaran umum ( go public), untuk itu notaris haruslah melakukan penelitian mendalam (due ligence) sebelum akta-akta tersebut dibuat.

Kata Kunci: Perseroan terbatas, Go Public, Notaris

\section{PENDAHULUAN}

Pasal 1 angaka 15 UUPM, Penawaran Umum adalah kegiatan penawaran efek yang dilakukan Emiten untuk menjual Efek kepada masyarakat berdasarkan tata cara yang diatur dalam Undang-Undang ini dan peraturan pelaksanaanya. Dengan demikian, penawaran umum tidak lain adalah kegiatan emiten untuk menjual efek yang dikeluarkan kepada masayrakat, yang diharapkan akan membeli dan dengan demikian memberikan pemasukan dana kepada Emiten baik untuk mengembangkan usahanya, membayar utang, atau kegiatan lainya yang diinginkan oleh Emiten tersebut. ${ }^{1}$

Penawaran Umum hanya dapat dilakukan oleh Emiten yang telah menyampaikan pernyataan pendaftaran kepada Badan Pengawas Pasar Modal dan Lembaga Keuangan (BAPEPAM-LK) yang sekarang diambil alih oleh Otoritas Jasa Keuangan (selanjutnya disebut OJK). OJK adalah lembaga yang dibentuk berdasarkan Undang-Undang Nomor 21 Tahun 2011 yang berfungsi menyelenggarakan sistem pengaturan dan pengawasan yang terintegrasi terhadap keseluruhan kegiatan di dalam sektor jasa dan keuangan. OJK adalah lembaga yang independen dan bebas dai campur tangan pihak lain, yang mempunyai fungsi, tugas dan wewang pengaturan, pengawasan, pemeriksaan, dan penyidikan. OJK didirikan untuk menggantikan peran

\footnotetext{
${ }^{1}$ Gunawan Widjaja dan Wulandari Risnamanitis D, Op Cit, hlm. 6.
} 
BAPEPAM-LK dalm pengaturan dan pengawasan pasar modal dan lembaga keuangan, dengan menggantikan peran Bank Indonesia dalam pengaturan dan pengawasan Bank, serta untuk melindungi konsumen industri jasa keuangan. Kewenangan dari Bank Indonesia setelah terbentuknya OJK akan fokus kepada kewenangan dalam hal kebijakan moneter. Kebijakan moneter yang dimaksud adalah kebijakan untuk mencapai dan menjaga kestabilan nilai rupiah yang dilakukan antara lain melalui pengendalian jumlah uang beredar dan suku bunga ${ }^{2}$

Dalam hal penawaran umum, pernyataan pendaftaran adalah dokumen yang wajib disampaikan kepada OJK oleh Emiten. Menurut Hamud M. Balfas, Emiten adalah pihak atau Perusahaan-perusahaan yang mengeluarkan efek berupa saham atau obligasi dan ditawarkan kepada masyarakat. ${ }^{3}$ Yang dimaksud dengan pihak atau perusahaan yang dapat melakukan Penawaran Umum adalah perseroan terbatas sebagaimana dimaksud dalam ketentuan UndangUndang Nomor 40 Tahun 2007 tentang Perseroan Terbatas (selanjutnya disebut UUPT). Perseroan Terbatas, yang selanjutnya disebut perseroan, adalah badan hukum yang merupakan persekutuan modal, didirikan berdasarkan perjanjian, melakukan kegiatan usaha dengan modal dasar yang seluruhnya terbagi dalam saham dan memenuhi persyaratan yang ditetapkan dalam udang-undang ini serta peratuan pelaksanaanya. Apabila suatu perseroan melakukan Penawaran Umum, maka Perseroan tersebut telah menjadi Perseroan terbuka.

Menurut ketentuan UUPT, Perseroan Terbuka adalah Perseroan Publik atau Perseroan yang melakukan penawaran umum saham, sesuai dengan ketentuan peraturan perundangundangan di bidang pasar modal. Defenisi Perseroan Publik menurut ketentuan UU Perseroan Terbatas adalah perseroan yang memenuhi kriteria jumlah pemegang saham dan modal disetor sesuai dengan ketentuan peraturan peraturan perundang-undangan dibidang pasar modal. Ketentuan lebih lanjut mengenai Perusahaan Publik yang diatur dalam peraturan perundangundangan dibidang pasar modal adalah UUPM. Defenisi Perusahaan Publik menurut UUPM adalah Perseroan yang sahamnya telah dimiliki sekurang-kurangnya oleh 300 (tiga ratus) pemegang saham dan memiliki modal disetor sekurang-kurangnya Rp. 3.000.000.000,00 (tiga milyar rupiah) atau suatu jumlah pemegang saham dan modal disetor yang ditetapkan dengan peraturan pemerintah.

Berdasarkan uraian tersebut diatas berarti suatu perseroan menjadi Perusahaan Publik dengan cara memenuhi kriteria yang dipersyaratkan dalam UUPM, pendapat yang sama juga dikemukakan oleh Hamud M. Balfas bahwa perusahaan menjadi Perusahaan Publik karena perusahaan memenuhi kriteria tertentu seperti yang ditetapkan oleh UUPM, yaitu karena merupakan suatu Perseroan Terbatas yang sahamnya telah dimilki modal disetor sekurangkurangnya tiga milyar rupiah, atau sutu jumlah pemegang saham dan modal disetor yang ditetapkan lain oleh Peraturan Pemerintah. ${ }^{4}$

Pada Bab VIII UUPM, diatur mengenai Profesi Penunjang Pasar Modal, yang salah satunya adalah Notaris. Pengertian Notaris terdapat Dalam Pasal 1 ayat (1) Undang-Undang Nomor 2 Tahun 2014 Tentang Perubahan Atas Undang-Undang Nomor 30 Tahun 2004 Tentang

\footnotetext{
${ }^{2}$ Adrian sutedi, Aspek hukum jasa keuangan, Raih Asa Sukses, Jakarta, 2014, hal.300

${ }^{3}$ Hamud M. Balfas, Hukum Pasar Modal Indonesia, jakarta : Tatanusa, 2006), hlm. 9.

${ }^{4}$ Hamud M. Balfas, Op Cit, Hlm. 10.
} 
Jabatan Notaris (Selanjutnya disebut UUJN) Notaris adalah Pejabat Umum yang berwenang membuat akta autentik dan memiliki kewenangan lainnya sebagaimana dimaksud dalam Undang-Undang ini atau berdasarkan Undang-Undang lainnya.

Ketentuan Pasal 1 UUJN tersebut merupakan pelaksanaan dari ketentuan Pasal 1868 Kitap Undang-Undang Hukum Perdata yang menentukan bahwa : suatu akta otentik yalah suatu akta yang, didalam bentuk yang ditentukan oleh undang-undang, dibuat oleh atau dihadapan pegawai umum yang berkuasa untuk itu ditempat dimana akte dibuatnya. Ketentuan pasal 1868 KUH Perdata tersebut hanya menjelaskan tentang apa yang disebut akta otentik, sedangkan apa yang disebut pejabat umum tidak dijelaskan dan untuk melaksanakan ketentuan dari Pasal 1868 KUH Perdata itulah pembuat Undang-Undang harus membuat perundang-undangan yang menunjuk pejabat umum yang berwenang untuk membuat akta otentik itu, sebagaimana ketentuan yang terdapat dalam Pasal 1 angka (1) UUJN tersebut.

Tidak semua Notaris yang dapat telibat dalam Penawaran Umum Perseroan. Notaris yang nantinya akan membantu perseroan untuk go public tersebut wajib terlebih dahulu terdaftar, sebagaimana yang disyaratkan dalam Pasal 64 ayat 2 UUPM dan pengaturanya di atur dalam Peraturan Otoritas Jasa Keuangan (POJK). Kedudukan dan tanggung jawab Notaris sebagai profesi penunjang pasar modal adalah sangat krusial jika dilihat dari adanya kewajiban pendaftaran yang merupakan syarat dari OJK agar Notaris dimaksud dapat melaksanakan tugasnya dan kewenanganya dalam membuat akta-akta pasar modal. Dalam UUPM tidak terdapat satu pasal pun yang merumuskan secara khusus mengenai kewenangan dari tugas Notaris dalam berkegiatan di pasar modal, oleh sebab itu Notaris dalam menjalan profesinya terikat pada tugas dan kewenangan sebagaimana diatur dalam UUJN.

Kewenangan Notaris berdasarkan Pasal 15 UUJN adalah : Notaris berwenang membuat Akta autentik mengenai semua perbuatan, perjanjian, dan penetapan yang diharuskan oleh peraturan perundang-undangan dan/atau yang dikehendaki oleh yang berkepentingan untuk dinyatakan dalam akta autentik, menjamin kepastian tanggal pembuatan Akta, menyimpan Akta, memberikan grosse, salinan dan kutipan Akta, semuanya itu sepanjang pembuatan akta itu tidak ditugaskan atau dikecualikan kepada pejabat lain atau orang lain yang ditetapkan oleh undangundang. Kewenangan pokok dari Notaris berdasarkan UUJN adalah membuat akta otentik. Akta sebagai surat bukti yang sengaja diadakan sebagai alat pembuktian, dalam zaman yang semakin maju akan semakin penting mengingat fungsi akta sebagai dokumen tertulis yang dapat memberikan bukti akan peristiwa hukum yang menjadi dasar dari hak atau perikatan. ${ }^{5}$

Oleh UUPM, profesi Notaris telah ditunjuk sebagai salah satu profesi penunjang pasar modal, tanggungjawab utama profesi penunjang pasar modal pada umumnya adalah membantu emiten dalam proses go public dan memenuhi persyaratan mengenai keterbukaan (disclousure) yang sifatnya terus menerus. ${ }^{6}$ Notaris dalam kegiatan pasar modal mempunyai tugas kunci, karena Notaris harus menyiapkan, membuat, dan merumuskan dokumen mengenai berbagai hubungan hukum yang terjadi antara berbagai pihak pada saat sebelum, ketika, dan sesudah

\footnotetext{
${ }^{5}$ Suharjono, 1995, Sekilas Tinjauan Akta Menurut Hukum, Sinar Grafika, Jakarta, h. 128

${ }^{6}$ M.Irsan Nasrudin dan Indara Surya, Op.Cit, hlm 160.
} 
penawaran umum. ${ }^{7}$ Secara khusus, peran notaris sebagai profesi penunjang kegiatan pasar modal sangat dibutuhkan, terutama dalam proses penawaran umum. ${ }^{8}$

Proses dari Penawaran Umum (go public) terdiri dari : tahap persiapan, tahap pernyataan pendaftaran, tahap penawaran umum, dan tahap pencatatan di bursa efek. Berdasarkan dari tahapan tersebut, tugas paling utama dari Notaris adalah pada tahap persiapan yang dilakukan oleh perseroan yaitu pembuatan akta-akta yang diperlukan untuk pernyataan pendaftaran ke OJK. Pada umumnya akta Notaris yang di perlukan dalam pernyataan pendafaran adalah Akta Perubahan Anggaran Dasar, akta Perjanjian Emisi Efek, dan akta Perjanjian Pengelolaan Administrasi Saham.

Hal yang paling mendasar dari dari penawaran umum (go public) adalah Perubahan Anggaran Dasar perseroan yang semula tertutup menjadi terbuka. Terkait dengan perubahan Anggaran Dasar perseroan tersebut, hanya dapat dilakukan berdasarkan Rapat Umum Pemegang Saham (RUPS) . Kemudian dari hasil keputusan RUPS tersebut dituangkan dalam bentuk akta notaril (relas akta) atau dapat pula berupa berita acara dibawah tangan, berdasarkan kewenangan direksi atau kuasa yang diberikan RUPS, hasil keputusan yang dibuat dalam bentuk berita acara dibawah tangan dan dibawa ke Notaris untuk dibuatkan Akta Peryataan Keputusan Rapat (PKR). Sebagai profesi yang berperan membantu emiten dalam hal mengubah Anggaran Dasar, Notaris haruslah memperhatikan tata cara dalam perubahan anggaran dasar dan mengenai isi dari anggaran dasar tersebut agar tidak bertentangan dengan peraturan perundang-udangan, ketertiban umum, dan atau kesusilaan. Selain membuatkan akta, Notaris juga berkewajiban untuk mengajukan permohonan persetujuan perubahan anggaran Dasar tersebut kepada Menteri Hukum dan Hak Asasi Manusia melalui Sistem Adminitrasi Badan Hukum (SABH).

Tahap persiapan penawaran umum ini merupakan tahap yang perlu mendapat perhatian dari Notaris karena Undang-undang memberikan wewenang kepada Notaris untuk membuat dan mengesahkan Berita Acara Rapat Umum Pemegang Saham perusahaan yang merencanakan untuk melakukan penawaran umum (go public) tersebut. Akta sebagai produk profesi Notaris secara yuridis adalah bukti formal yang memuat informasi tentang tindakan-tindakan hukum yang dilakukan oleh pihak-pihak yang melakukan kegiatan di Pasar Modal. Dengan adanya akta yang dibuat oleh Notaris, maka kepastian hukum dapat terjamin, karena akta otenik tersebut memastikan isi kebenaran yang nyata dari para pihak dan akan mempunyai kekuatan pembuktian lahiriah, formal, dan materilnya nantinya.

\section{METODE PENELITIAN}

\section{Pendekatan Masalah}

Pendekatan masalah yang akan dipergunakan dalam penelitian ini adalah pendekatan yuridis empiris, yaitu suatu penelitian disamping melihat aspek hukum positif juga melihat seperti apa penerapan dilapangan dan masyarakat, data yang diteliti awalnya data sekunder untuk kemudian dilanjutkan dengan penelitian terhadap data primer dilapangan, yaitu

\footnotetext{
${ }^{7}$ Ana Rokhmatussa'dyah dan Suratman, Hukum Investasi dan Pasar Modal, jakarta, Sinar Grafika, 2015, hlm. 179.

${ }^{8}$ G.H S. Lumban Tobing, Peraturan Jabatan Notaris, Jakarta: Penerbit Erlangga, 1996, hlm 3.
} 
penelitian terhadap para pihak-pihak yang terkait dalam pelaksanaan tugas jabatan Notaris di pasar modal.

2. Sifat Penelitian

Penelitian ini merupakan penelitian yang bersifat deskriptif analitis yaitu menggambarkan atau memaparkan dan menjelaskan objek penelitian secara lengkap, jelas dan secara objektif yang ada kaitannya dengan permasalahan. Dimana dalam penelitian ini penulis menggambarkan proses perubahan akta dalam rangka go public Perseroan Terbatas.

\section{HASIL DAN PEMBAHASAN}

\section{Perubahan Substansi Anggaran Dasar Perseroan Terbatas Dalam Rangka Penawaran Umum (Go Public) Perseroan Terbatas.}

Keterlibatan seorang Notaris pada dasarnya di mulai dari berdirinya sebuah perusahaan, namun dalam hal perusahaan ingin melakukan atau turut serta dalam pasar modal, maka Notaris dalam hal ini yang telah memiliki kewenangan izin akan turut serta dalam persiapan untuk perusahaan melakukan go publik, baik pada saat perencanaan maupun setelah penawaran umum di pasar perdana. Berdasarkan pasal 64 ayat (2) UUPM untuk dapat melakukan kegiatan di bidang pasar modal, perofesi penunjang wajib terlebih dahulu terdaftar di Bapepam (OJK). Menindaklanjuti dari ketentuan UUPM tersebut bagi Notaris yang akan melakukan kegiatan di pasar modal diatur dalam Peraturan Otoritas Jasa Keuangan Nomor 67 /Pojk.04/2017 Tentang Notaris Yang Melakukan Kegiatan Di Pasar Modal (selanjutnya disebut POJK 67). Dalam Bab II POJK 67, pada Pasal 2 disebutkan bahwa Notaris yang melakukan kegiatan di bidang pasar modal wajib terlebih dahulu terdaftar di OJK dan memenuhi persyaratan sebagaimana diatur dalam Peraturan Otoritas Jasa Keuangan.

Adapun Persyaratan pendaftaran Notaris tersebut terdapat dalam Pasal 3 POJK 67 meliputi:

1. telah diangkat sebagai notaris oleh kementerian yang membawahi bidang kenotariatan serta telah diambil sumpahnya sebagai notaris oleh instansi yang berwenang;

2. telah menjadi anggota Organisasi Notaris;

3. memiliki akhlak dan moral yang baik;

4. tidak pernah melakukan perbuatan tercela dan/atau dihukum karena terbukti melakukan tindak pidana di bidang jasa keuangan;

5. bersikap independen, objektif, dan profesional dalam melakukan kegiatan di bidang pasar modal;

6. menaati kode etik yang ditetapkan oleh Organisasi Notaris;

7. memiliki keahlian di bidang pasar modal yang dipenuhi melalui program Pendidikan Profesi dengan jumlah paling sedikit 30 (tiga puluh) satuan kredit profesi;

8. tidak bekerja rangkap sebagai profesi penunjang pasar modal lainnya dan/atau jabatan lain yang oleh ketentuan peraturan perundang-undangan dilarang untuk dirangkap dengan jabatan notaris; dan 
9. tidak pernah dikenakan sanksi administratif berupa pembatalan surat tanda terdaftar dari Otoritas Jasa Keuangan.

Pada pasal 4 dan 5 juga diatur Mengenai prosedur untuk menjadi Notaris Pasar Modal yaitu Mengajukan kepada OJK surat permohonan pendaftaran Notaris sebagai Profesi Penunjang Pasar Modal, dilampiri dengan dokumen KTP dan NPWP; SK pengangkatan Notaris dan Berita Acara Sumpah Notaris; Surat Prnyataan tak pernah mlakukan prbuatan tercela dan/atau trbukti tndak pidana di bdang keuangan; Sertifikat Pelatihan Notaris Pasar Modal yg diakui OJK; surat pernyataan bahwa Notaris sanggup mengikuti secara terus menerus program Pendidikan Profesi Lanjutan (PPL) di bidang kenotariatan dan peraturan perundangundangan di bidang Pasar Modal; Surat Pernyataan Notaris sanggup melakukan pemriksaan sesuai dengan Kode Etik Profesi dan UUJN serta selalu bersikap independen dalam menjalankan kegiatan; Kartu Anggota INI; Surat Pernyataan bersedia menjadi anggota INI sesudah mendapat STTD (Surat Tanda Terdaftar) dari OJK dan akan menyerahkan bukti keanggotaan INI kepada OJK; dan Surat Pernyataan bahwa Notaris bersedia dalam rangka pemenuhan Kode Etik Profesi dan UUJN dalam rangka menjalankan kegiatannya

Setelah Notaris mengajukan pendaftaran dan OJK menyatakan Notaris tersebut memenuhi syarat sebagai profesi penunjang. Selanjutnya OJK akan menetapkan surat tanda terdaftar profesi penunjang pasar modal (STTD) kepada Notaris tersebut, yang mana hanya mempunyai masa berlaku selama 5 (lima) tahun dan apabila masa berlakunya telah berakhir dalam waktu 90 (hari) Notaris dapat mengajukan kembali permohonan pendaftaran ke OJK. Jika tidak diperpanjang maka Notaris tersebut dilarang untuk melakukan kegiatan di pasar modal

Setelah Notaris mendapatkan persetujuan atau Notaris memperoleh STTD dari OJK barulah Notaris tersebut dapat menjalankan profesinya untuk melakukan kegiatan di pasar modal nantinya. Seorang Notaris selain telah mendapatkan izin untuk menjadi seorang Notaris pasar modal, maka untuk menjalankan keahliannya harus tetap menjadi profesional yang mandiri serta mampu mengelola data demi kepentingan banyak orang terkhusus pihak-pihak yang melakukan kegiatan di pasar modal, dan menjaga nama baik selaku Notaris. Hal ini bertujuan agar Notaris dapat memenuhi kebutuhan pengguna jasa dan mengemban kepercayaan publik khususnya di sektor pasar modal dan pada umumnya di sektor jasa keuangan. Untuk tetap menjaga dan meningkatkan hal tersebut, Notaris dituntut untuk mengikuti program pendidikan profesional berkelanjutan dan melaporkan kegiatan yang dilakukan di sektor pasar modal maupun perubahan atas data dan informasi terkait Notaris kepada OJK sebagaimana diatur dalam Pasal 17 ayat (1) POJK 67.

Seluruh perusahaan dalam rangka melakukan listing di pasar modal sudah seharusnya perusahaan tersebut melakukan beberapa tindakan untuk melewati atau memenuhi tahap-tahap yang telah di tentukan oleh UUPM. Suatau langkah yang di tempuh adalah melakukan penawaran saham perdana yang dilakukan perusahaan kepada publik atau umumnya dikenal Initial Publik Offerings (IPO) yang merupakan jalan awal bagi sebuah perusahaan sebelum berubah status menjadi perusahaan go public. 
Tugas seorang Notaris pasar modal dalam melakukan Penawaran Umum (go public) dapat dibagi dalam beberapa bagian seperti: ${ }^{9}$

\section{A. Tugas Notaris Pada Saat Melakukan Persiapan Penawaran Umum (Go Public). 1) Tahap Persiapan Internal Perusahaan}

Tahap paling awal suatu perusahaan untuk go public adalah tahap persiapan internal perusahaan. Di dalam praktek, Notaris sebagai salah satu profesi penunjang yang berperan dalam membantu calon emiten untuk melakukan penawaran umum (go public), pada umumnya tidak hanya berperan dalam membuatkan akta Perubahan Angaran dasar saja, yang mana akta tersebut diperlukan pada saat Pernyataan pendaftran Kepada OJK. Selain Akta Perubahan Anggaran Dasar masih banyak akta yang dapat dibuat oleh Notaris dalam rangka membantu peseroan dalam melakukan penawaran umum (go public), diantaranya yaitu, Akta Perjanjian Penjaminan Emisi Efek, akta Perjanjian Administrasi Pengelolaan Saham, akta pernyataan waran, dan lain sebagainya. Tapi semua akta-akta tersebut dibuat adalah pada tahap pendahuluan atau ketika perseroan sudah akan (go public). Namun pada umumnya, Notaris berperan dalam membantu perusahaan dimulai dari tahap persiapan-persiapan yang dilakukan oleh perseroan tersebut, karena dengan begitu Notaris akan mendapatkan lebih banyak pekerjaan sehingga Notaris mendapakan bayaran (fee) yang lebih dari pihak perseroan. Biasanya pekerjaan dari Notaris dalam rangka mempersiapkan perusahan go public adalah mengenai restrukturisasi permodalan dan saham serta aset-aset perusahaan. Restrukturisasi permodalan dan saham ini pada dasarnya terkait dengan peningakatan modal perusahaan calon emiten. Tugas Notaris disini biasanya adalah membuatkan akta-akta mengenai peningkatan dari modal dasar dan modal disetor, serta mengenai penurunan nilai nominal saham perusahaan berserta dengan anak-anak perusahaannya. Disini Notaris akan bertugas utuk membuatkan akta-akta tersebut.

Terkait dengan Aset perusahaan, pada perusahaan yang masih dalam bentuk perusahaan keluarga seringkali tercampur antara aset pribadi dan aset perusahaan, hal-hal yang seperti ini harus dibereskan terlebih dahulu oleh perusahan yang akan go public, jadi apa yang menjadi aset perusahaan harus disahkan dulu secara hukum. Banyak dari perusahaan calon emiten yang asetnya masih atas milik pribadi, baik itu atas nama direktur ataupun pemegang saham. Jadi semua aset-aset dari perusahan itu yang masih bersertifikat hak milik, terlebih dahulu diturunkan haknya, sehingga pada laporan buku keuangan perusahaan diakui sebagai aset perusahan, dan hal tersebut juga akan dibantu oleh Notaris.

Selain bertugas membantu dalam hal menstrukturisasi permodalan dan saham serta aset perusahaan, Notaris juga dapat memberikan penyuluhan hukum atau memberikan konsultasi, khususnya mengenai syarat-syarat dan ketentuan yang harus dipenuhi dalam proses go public, sehingga tidak atau terhindar dari kemungkinan transaksi tersebut dilaksanakan dengan keadaan yang batal demi hukum atau dapat dimintakan pembatalan di depan pengadilan. Kewenangan memberikan penyuluhan hukum ini diinterpretasikan dari

\footnotetext{
${ }^{9}$ Wawancara dengan Notaris Pasar Modal Sugih Haryati S.H M.kn.
} 
Pasal 15 ayat (2) huruf e UUJN yang berbunyi : "Notaris berwenang pula memberikan penyuluhan hukum sehubungan dengan pembuatan akta".

\section{2) Pendahuluan Go Public}

Setelah proses persiapan selesai dilakukan dan calon Emiten telah yakin bahwa perusahaannya telah siap untuk go public, maka mulailah dilakukan kegiatan-kegiatan yang termasuk ke dalam proses pendahuluan untuk melakukan go public. Proses pendahuluan go public yang berkaitan dengan tugas Notaris antara lain sebagai berikut:

\section{a. Berita acara Rapat Umum Pemegang Saham (RUPS) Persetujuan Go Publik dan Perubahan Anggaran Dasar}

Langkah pertama yang harus dilakukan dalam proses pendahuluan adalah menyamakan persepsi dan visi di antara para pihak manajemen dan pemegang saham pendiri (founders) mengenai konsep go public dan kaitannya dengan aktivitas perusahaan. Bila inisiatif untuk melakukan go public berasal dari founders, biasanya rencana tersebut tidak mengalami hambatan yang berarti Namun apabila inisiatif berasal dari pihak manajemen (yang independen), maka pihak manajemen tersebut harus dapat meyakinkan founders bahwa go public akan memberikan konstribusi positif kepada perusahaan di masa mendatang. Dengan demikian tahap yang paling awal yang harus dilewati dalam proses pendahuluan adalah meminta persetujuan atas rencana go public tersebut dari para pemegang saham di dalam RUPS. Jadi RUPS merupakan titik dasar dalam suatu perusahaan yang ingin melakukan penawaran perdana.

Direksi dalam mempersipakan RUPS dalam praktinya akan dibantu oleh Notaris yang akan ditunjuk dalam rangka penyelenggaraan RUPS tersebut, terkait dengan persiapan RUPS dalam rangka Go Public tersebut, perlu disiapkan secara matang khususnya mengenai agenda yang akan diajukan dan dimintakan persetujuanya pada para pemegang saham lama dalam RUPS. Dalam praktik, hal-hal yang dimintakan persetujuan kepada para pemegang saham lama dalam RUPS dalam rangka go public ini adalah persetujuan antara lain:

a) Persetujuan rencana perseroan untuk melakukan penawaran umum perdana saham peseroan kepada masyarakat (penawaran umum) dan mencatatkan saham-saham perseroan tersebut pada Bursa Efek Indonesia

b) Persetujuan perubahan status perusahaan dari PT Tertutup menjadi PT terbuka;

c) Persetujuan mengeluarkan saham dalam simpanan/portrpel perseroan dan menawarkan/menjual saham baru yang akan dikeluarkan dari portepel tersebut melalui Penawaran Umum kepada masyarakat.

d) Persetujuan perubahan nilai nominal saham;

e) Perubahan Anggaran Dasar perusahaan untuk disesuaikan dengan ketentuan dan peraturan perundang-undangan di bidang Pasar Modal;

f) Memberikan kuasa kepada direksi perusahaan untuk melaksanakan tindakan yang diperlukan sehubungan dengan rencana go public perusahaan; 
g) Persetujuan penegasan kembali susunan direksi dan komisaris perseroan serta pengangkatan komisaris independen;

Setelah menyusun agenda RUPS secara matang, maka direksi perusahaan untuk mengawali tahap go public harus melaksanakan RUPS untuk meminta persetujuan atas agenda-agenda yang telah disusunya terkait dengan rencana go publik.

Sebelum melaksanakan RUPS Notaris wajib memeriksa dokumen-dokumen yang berkaitan dengan proses transaksi penawaran perdana:

a) Akta pendirian dan Anggaran Dasar Perusahaan beserta perubahanya yang paling akhir;

b) Seluruh perubahan

c) Permodalan dan Saham

d) Direksi dan Komisaris

e) Pesetujuan dan Keputusan yang diambil dalam RUPS.

Selain memeriksa dokumen-dokumen diatas Notaris juga harus meneliti hal-hal yang berkaitan dengan keabsahan Penyelenggraan RUPS, dimana penyelenggaraan RUPS ini harus sesuai dengan ketentuan-ketentuan dalam Anggaran Dasar perseroan dan UUPT. Agar nantinya tidak terjadi kesalahan dalam tata cara penyelenggaraan RUPS, sehingga hasil dari RUPS tersebut terutama pada Perubahan Anggaran dasar tidak dapat dan/atau ditolak persetujuanya oleh menteri. Persyaratan penyelenggaraan RUPS tersebut adalah mengenai:

a) Tempat diselenggarakanya RUPS.

b) Tata cara pemberitahuan dan pemanggilan RUPS yang telah dilakukan perseroan.

c) Pemenuhan ketentuan kuorum dan kehadiran dan pemenuhan persyaratan pengambilan keputusan.

d) Meneliti keabsahan pemegang saham yang hadir.

Memeriksa hal-hal tersebut diatas sangat perlu dilakukan oleh Notaris, karena menyangkut keabsahan penyelenggaaan RUPS, apabila tidak sesuai dengan ketentuan atau tata cara yang diatur oleh UUPT dan Anggaran Dasar perseroan, maka Perubahan Anggaran Dasar tersebut nantinya akan ditolak oleh Mentri Hukum dan Hak Asasi Manusia. Pada tahap penyelenggaan RUPS, tugas utama dari Notaris adalah membuat Risalah Berita Acara RUPS yang memuat segala sesuatu yang dibicarakan dan diputuskan dalam RUPS. Selain itu pada saat penyelenggraan RUPS, Notaris juga bertugas untuk menjaga hal-hal yang dibicarakan dalam rapat adalah sesuai dengan agenda rapat yang sudah diumumkan dalam panggilan RUPS. Selama jalanya RUPS, Notaris juga berwenang untuk memberikan penyuluhan hukum terhadap isi dari akta yang akan dibuat tersebut ( Akta Berita Acara RUPS)

Setelah menelaah dan memeriksa segala hal yang berkaitan dengan proses go publik maka selanjutnya adalah melaksanakan RUPS dengan agenda rapat persetujuan untuk go public dan perubahan $\mathrm{AD}$ emiten, hal ini agar emiten tersebut dapat melakukan penawaran umun perdana dan menjadi perusahaan go public, karenanya dalam RUPS status badan hukumnya harus diubah dari Perseroan Tertutup menjadi Perseroan Terbuka 
(PT.tbk). Selain itu Anggaran Dasar perusahaan harus dirubah untuk disesuaikan dengan peraturan di bidang Pasar Modal, yaitu Keputusan Ketua Badan Pengawas Pasar Modal Nomor KEP-179/BL/2008 tanggal 14 Mei 2008 tentang Pokok- Pokok Anggaran Dasar Perseroan Yang Melakukan Penawaran Umum Efek Bersifat Ekuitas dan Perusahaan Publik (untuk selanjutnya disebut Peraturan 179).

Pada tahap ini seorang Notaris dituntut ketelitianya dan pemahaanya terhadap sustansi dari pasal-pasal yang akan dituangkan ke dalam Anggaran Dasar tersebut, agar sejalan dengan peraturan bidang pasar modal dan peraturan lainya yang terkait. Ketentuanketentuan dalam Anggaran Dasar yang perlu dirubah atau disesuaikan tersebut adalah Nama Dan Tempat Kedudukan; Jangka waktu berdirinya perseroan. Maksud dan tujuan serta kegiatan usaha; Permodalan; Saham; Surat Saham; Penggantian Surat Saham; Daftar Pemegang Saham dan Daftar Khusus; Penitipan Kolektif; Pemindahan Hak Atas Saham; Direksi; Tugas dan Wewenang Direksi; Rapat direksi; Dewan Komisaris; Tugas Dan Wewenang Dewan Komisaris; Rapat Dewan Komisaris; Rencana Kerja, Laporan Tahunan, Laporan Kuangan Tahunan, dan Penggunaan Laba; Rapat Umum Pemegang Saham (RUPS); Rapat Umum Pemegang Saham Tahunan; Rapat Umum Pemegang Saham Luar biasa; Tempat dan Pemanggilan Rapat Umum Pemegang Saham; Pimpinan, Risalah dan Ringkasan Risalah Rapat Umum Pemegang Saham; Kuorum, Hak Suara dan Keputusan; Penggunaan Lab; Penggunaan Dana Cadangan; Pengubahan Angaran Dasar; Penggabungan, Peleburan, pengambilalihan dan pemisahan; Pembubaran dan Likuidasi; Tempat Tinggal (Domisili) dan Peraturan Penutup

\section{b. Penjaminan Emisi Efek.}

Proses Penjaminan Emisi atau lebih dikenal dengan istilah Underwriting dilakukan antara Emiten dan Penjamin Emisi Efek yang dituangkan dalam suatu Perjanjian Penjaminan Emisi Efek yang dibuat pada tahap persiapan. Disinilah peranan Notaris sangat dibutuhkan untuk membuat akta Perjanjian Penjaminan Emisi Efek.

Secara umum Perjanjian Emisi Efek antara Emiten dan Penjamin Emisi Efek terdiri dari dua bentuk, yaitu :

a) Full Commitment,

b) Best Effort,

Pada umumnya dalam proses penawaran umum perdana penjaminan emisi yang digunakan adalah sistem full commitment karena dengan adanya kewajiban untuk membeli seluruh sisa saham yang tidak habis terjual, maka Penjamin Emisi akan berusaha dengan sebaik-baiknya untuk menjual seluruh saham yang ditawarkan oleh Emiten. Apabila menggunakan sistem best effort akan menimbulkan kemungkinan bahwa Emiten akan mendapatkan hasil penjualan saham kurang dari yang diharapkan dikarenakan tidak mendapat jaminan dari Penjamin Emisi bahwa semua saham yang ditawarkan akan habis terjual.

Seorang Notaris yang hendak menuangkan perjanjian Penjaminan Emisi Efek haruslah memahami dan menguasai peraturan perundang-undangan di bidang Pasar Modal 
supaya perjanjian yang dibuatnya tersebut tidak bertentangan dengan peraturan yang berlaku. Untuk itu, seorang Notaris perlu membekali dirinya dengan pengetahuan yang cukup tentang aspek-aspek penawaran umum perdana saham dan selalu mengikuti pelatihan yang diadakan oleh OJK secara berkala. Dalam menyusun Perjanjian Penjaminan Emisi Efek, Notaris tidak hanya harus memperhatikan kepentingan Emiten dan kepentingan Penjamin Emisi Efek, namun juga kepentingan segenap Penjamin Pelaksana Emisi Efek dan kepentingan masyarakat calon pemodal yang nantinya ikut serta dalam penawaran umum perdana saham.

Segala sesuatu yang diatur didalam perjanjian ini merupakan kesepakatan dari para pihak yaitu emiten (perusahaan) dan penjamin emisi (underwiter). Notaris mempersipkan mengenai isi perjajian tetapi Notaris tidak berhak mencampuri isi dan akibat dari perjanjian yang berkaitan dengan komitmen underwriter. Disini Notaris hanya dapat memberikan penyuluhan hukum yang diperlukan mengenai isi akta dan akibat dari perjanjian ini terutama mengenai komitmen penjamin emisi di dalam melaksanakan penawaran umum.

Biasanya sebelum membuat perjanjian, penjamin emisi mengadakan rapat yang dilaksanakan oleh manajemen perusahaan yang dihadiri oleh Emiten, Akuntan, Konsultan hukum dan Notaris. Menurut Notaris Sugih Haryati, S.H.Mkn., emiten dan underwriter didalam rapat juga meminta pendapat Notaris mengenai isi perjanjian emisi efek karena bagaimanapun juga underwriter memegang peranan penting didalam sukses atau tidaknya proses penawaran umum yang dilaksanakan dan dikarenakan Notaris merupakan orang yang tidak berpihak maka harapan dapat memberikan saran hukum yang seimbang oleh karena itu Notaris juga perlu mengetahui aspek bisnis dan ekonomi yang berkaitan dengan Pasar Modal.

\section{c. Perjanjian Pengelolaan Administrasi Saham}

Dalam rangka Go Public, Emiten perlu untuk membuat Perjanjian Pengelolaan Adminitrasi saham dengan Pihak Biro Administrasi Efek (BAE) sebagai salah satu Lembaga Penunjang Pasar Modal yang akan membantu Emiten untuk mengadministrasikan saham-sahamnya yang biasanya dibuat dalam bentuk akta Notaris. Apabila Emiten telah menjadi perusahaan publik dan melakukan pencatatan di bursa, maka Emiten memerlukan peranan dari Biro Administrasi Efek yang akan menangani pencatatan dan administrasi saham yang telah dicatatkan di bursa, antara lain mengenai pemeliharaan Daftar Pemegang Saham Emiten termasuk setiap pencatatan pemindahan hak atas saham. Biro Administrasi Efek inilah yang akan mengeluarkan bukti kepemilikan yang sah atas saham-saham Emiten berdasarkan Daftar Pemegang Saham. Namum perjanjian dengan BAE pada saat ini sudah tidak berlaku lagi dan diganti pengelolaanya dengan PT. KPEI (Kliring Penjamin Efek Indonesia) yang bertugas sebagai lembaga penyimpan dan penyelesaian saham.

\section{d. Pernyataan Penerbitan Waran}

Dalam persiapan untuk go public pada umumnya perusahaan akan mempunyai strategi tertentu untuk mendapatkan dana dari masyarakat yaitunya dengan menerbitkan 
waran, dalam proses go public waran ini hanyalah bersifat opsional. Menurut UUPM, dalam penjelasan Pasal 1 angka 5, Waran adalah efek untuk memesan saham dari perusahaan tersebut pada harga tertentu setelah 6 (enam) bulan atau lebih sejak efek dimaksud diterbitkan. Defenisi waran ditentukan dalam peraturan Bapepam-LK nomor IX.D.1 tentang hak memesan Efek Terlebih Dahulu, yang dalam angka 1 huruf $b$ menyebutkan bahwa: "waran adalah efek yang diterbitkan oleh suatu perusahaan yang memberi hak kepada pemegang saham dari perusahaan tersebut pada haraga tertentu untuk jangka waktu 6 (enam) bulan atau lebih sejak diterbitkanya waran tersebut"

Pada penawaran umum saham, waran menjadi daya tarik kepada calon investor untuk membeli saham yang ditawarkan perusahaan yang bersangkutan, karena waran tersebut diberikan secara cuma-cuma atas pembelian saham yang ditawarkan. Dikatakan secara Cuma-Cuma, maksudnya bahwa waran itu melekat pada saham yang diterbitkan tersebut, sehingga setiap pembelian saham akan mendapat waran, sesuai dengan ketentuan dalam penawaran umum saham yang bersangkutan, waran dapat menjadi daya tarik bagi calon investor untuk membeli saham dalam penawaran umum karena hak yang diberikan waran kepada pemegangnya, yaitu hak untuk membeli saham dari perusahaan penerbit waran pada harga dan waktu tertentu. Harga saham dapat berubah-ubah setelah penawaran umum. Ketika harga saham naik lebih tinggi dari harga pelaksanaan waran, pemilik waran akan mendapatkan keuntungan karena membeli saham dengan haraga pelaksanaan waran tadi, namun sebaliknya, apabila saham turun lebih rendah dari harga pelaksanaan, waran tidak dapat digunakan membeli saham dengan harga yang lebih rendah dari harag pelaksanaan waran.

Pemegang waran berhak sepehuhnya untuk menggunakan atau tidak menggunakan haknya untuk membeli saham emiten yang bersangkutan. Sebagai contoh, jika seorang investor membeli waran pada harga Rp. 200,00 (dua ratus rupiah) per lembar dengan harga pelaksanaan Rp. 1.500,00 (seribu lima ratus rupiah), dan pada tanggal pelaksanaan, harga saham perushaan meningkat menjadi Rp. 1.800,00 (seribu delapan ratus rupia) per lembar saham, ia akan membeli saham perusahaan tersebut dengan harga 1.700,00 (seribu tujuh ratus rupiah). Jika ia lansung membeli saham perusahaan tersebut di pasar sekunder, ia harus membayar sebesar Rp. 1.800,00 (seribu delapan ratus rupiah) per saham. Sealiknya, jikaharag saham pada tanggal pelaksanaan waran menjadi lebih rendah dari harga pelaksanaan waran, pemilik waran tidak akan melakukan pelaksanaan waran, sehingga ia hanya akan mengalami kerugian atas harga beli waran tersebut.

Untuk penerbitan waran perlu dilakukan pernyataan mengenai penerbitan waran. Pernyataan penerbitan waran tersebut dilakukan oleh emiten atau perusahaan publik yang bersangkutan dengan cara membuat akta penerbitan Waran dihadapan Notaris sebelum penerbitan waran. Akta pernyataan yang dibuat oleh notaris ini merupakan pernyataan bahwa perseroan akan mengeluarkan waran dengan jumlah dan syarat-sayarat tertentu yang dinyatakan dalam akta Pernyataan penerbitan Waran. 


\section{e. Perjanjian Pengelolaan Administrasi Waran}

Sebagai mana dikemukakan diatas, salah satu isi dalam akta pernyataan penerbitan waran adalah mengenai Biro Administrasi Efek (BAE) yang akan ditunjuk sebagai pengelola administrasi waran. Penunjukan pengelolaan administrasi waran tersebut dilakukan dengan membuat akta Perjanjian pengelolaan administrasi waran antara emiten atau perusahaan publik yang bersangkutan dengan Biro Administrasi Efek (BAE) yang akan ditunjuk sebagai pengeloala adminitrasi waran, pembuatan akta ini dilakukan dihadapan Notaris Pasar Modal.

Setelah keinginan go public disepakati dan diputuskan, untuk menjadi perusahaan yang sahamnya dicatatkan dan diperdagangkan di Bursa Efek Indonesia (yang selanjutnya disebut BEI), direksi perusahaan mengajukan surat pernyataan kehendak atau leter of intent kepada BEI yang kemudian akan ditinjak lanjuti dengan pembuatan perjanjian pendahuluan pencatatan efek di Bursa Efek Indonesia. Surat tersebut dilengkapi dokumendokumen mengenai profil perusahaan, besarnya jumlah saham yang akan dijual, rencana penggunaan dan yang masuk serta masalah-masalah yang dihadapi, dan pendapat hukum dari Konsultan yang ditunjuk dalam rangka go public.

Setelah surat pernyataan kehendak perusahaan untuk go public diajukan ke BEI, langkah selanjutnya perusahaan bersama-sama underwriter, lembaga serta profesi penunjang mengadakan mini expose dihadapan Bursa Efek Indonesia untuk mempresentasikan maksud dan tujuan perusahaan dalam rangka go public tersebut. Dalm hal BEI telah memperoleh segala informasi yang dibutuhkan, kemudian perusahaan di dampingi underwriter, lembaga dan profesi penunjang melakukan koordinasi dalam rangka persipan penandatanganan perjanjian pendahuluan dengan BEI dapat dilansungkan. Selain itu perusahaan juga perlu menyampaikan permohonan pendaftaran saham untuk dititipkan secara kolektif (scriples) di Kustodian Sentral Efek Indonesia (KSEI).

\section{B. Tugas Notaris pada proses pelaksanaan Go Public}

Tugas Notaris pada saat proses pelaksanaan go public ini pada umumnya terkait dengan perubahan-perubahan Perjanjian Emisi Efek dan berbarengan dengan perubahan Pengelolaan Administrasi Saham. Dalam pembuatan Akta Perjanjian Emisi Efek yang telah dibuat sebelumya terdapat hal-hal yang belum dicantumkan. Oleh karena itu, maka perlu diadakan beberapa perubahan atas perjanjian tersebut, yang antara lain mengenai harga saham perdana yang akan ditawarkan, jadwal waktu emisi, pembentukan sindikasi dari para penjamin pelaksana emisi efek dan hal-hal lain yang belum tercantum dalam perjanjian tersebut. Terkait dengan masuknya sindikasi penjamin emisi efek, maka nantinya Notaris juga akan membuatkan perjanjian antar para penjamin efek. Untuk Perubahan Akta Perjanjian Pengelolaan Administrasi Saham, pada saat ditandatanganinya Perubahan Perjanjian Penjaminan Emisi Efek dalam bentuk akta Notaris, maka ditandatangani pula Perubahan Perjanjian Pengelolaan Administrasi Saham. Untuk perubahanya adalah berkaitan dengan jumlah saham yang akan dijual kepada masyarakat.

Setelah tahap persiapan selesai dilakukan dan mendapakan Perjanjian Pendahuluan Pencatatan Saham dari Bursa Efek Indonesia, calon emiten harus mengajukan pernyataan 
pendaftaran dan dokumen-dokumen termasuk salinan akta-akta yang diberikan oleh Notaris kepada OJK sesuai dengan peraturan Bapepam-LK No. IX.A.1 Tentang Ketentun Umum Pengajuan Pernyataan Pendaftaran yang merupakan lampiran dari keputusan ketua Bapepam-LK No. Kep-690/BL/2011 tanggal 30 Desember 2011, dimana dokumen yang harus diajukan dalam bentuk serta mencakup informasi sesuai dengan peraturan Bapepam-LK No.IX.A.1 dan tata cara pengajuan pernyataan pendaftaran dalam rangka Penawaran Umum sebagaimana diatur dalam peraturan Bapepam-LK No. IX.A.2 yang merupakan lampiran dari keputusan Bapepam-LK No. Kep-122/BL/2009 tanggal 29 Mei 2009.

Perusahaan calon emiten diwajibkan meyampaikan dokumen pernyataan pendaftaran kepada OJK dalam rangkap 4 (empat) beserta dokumen pendukungnya, walaupun informasi tertentu seperti jumlah dan harga penawaran, penjaminan emisi efek belum bisa ditentukan, pada saat pengajuan pernyataan pendaftaran ini, perusahaan calon emiten belum diperbolehkan untuk mengumumkan Prospektus Ringkas yang merupakan bagian dari pernyataan Pendaftaran sampai dengan diterimanya pernyataan dari OJK yang menyatakan bahwa calon emiten wajib mengumumkan prospektus ringkas.

Setelah perusahaan calon emiten memasukan pernyataan pendaftaran secara resmi kemudian OJK melakukan penelaahan terhadap dokumen-dokumen pernyataan pendaftaran tersebut. Dalam masa penelaahan tersebut, OJK dapat meminta perubahan dan/atau tambahan informasi kepada calon emiten untuk tujuan penelaahan atau pengungkapan keterbukaan kepada masyarakat calon investor. Terhitung sejak tanggal OJK mengeluarkan permintaan perubahan/tambahan informasi, maka emiten diwajibkan untuk menyampaikan perubahan tersebut dan tambahan informasi paling lama 10 (sepuluh) hari kerja.

Sesuai dengan Peraturan Otoritas Jasa Keuangan Nomor 7 /Pojk.04/2017 Tentang Dokumen Pernyataan Pendaftaran Dalam Rangka Penawaran Umum Efek Bersifat Ekuitas, Efek Bersifat Utang, Dan/Atau Sukuk, emiten wajib mengumumkan Prospektus Ringkas yang merupakan bagian dari dokumen dalam Pernyataan Pendaftaran Penawaran Umum. Setelah melakukan pengumuman prospektus ringkas tersebut pada masyarakat emiten sudah dapat melakukan penawaran awal atau dikenal dengan istilah bookbuilding dan/atau menyebarkan informasi terkait penawaran umum. Pada tahap penyampaian informasi dan keterbukaan lainya, emiten wajib menyampaikan informasi mengenai jumlah dan harga penawaran efek, penjamin emisi efek, konfirmasi tersebut disampaikan kepada OJK paling cepat 7 (tujuh) hari kerja setelah pengumuman propektus ringkas. Setelah calon emiten telah mengkonfirmasi ada atau tidaknya perubahan informasi atau telah menyampaikan informasi mengenai jumlah dan harga efek, penjamin emisi efek dan setelah kecukupan dan objektifitas informasi yang diungkap dalam pernyataan pendaftaran selesai ditelaah oleh OJK, maka OJK akan mengeluarkan pernyataan Efektif atas pernyataan Pendaftran yang diajukan tersebut. Selanjutnya emiten diwajibkan menyediakan prospektus bagi masyarakat atau calon pembeli dan menyampaikan prospektus dalam bentuk cetak kepada OJK sebanyak 5 (lima) eksemplar berserta salinan elektroniknya. Paling lambat 1 (satu) hari kerja setelah Pernyataan Efektif Pernyataan Pendaftaran dari OJK keluar emiten diwajibkan mengumumkan perbaikan atau tambahan informasi atas prospektus 
Ringkas, khususnya mengenai tambahan informasi tentang tanggal efektif. Disamping kewajiban melalui surat kabar, emiten dapat juga mengumumkan informasi tersebut dalm media masa yang lain, dalam praktik, media masa yang juga digunakan untuk melakukan pengumuman adalah website BEI, bersamaan dengan diumumkanya tambahan informasi, masa penawaran umum sudah dapat dilaksanakan.

Setelah surat izin emisi efek diterima oleh emiten, maka emiten melalui penjamin emisi efek dan agen penjual melakukan penjualan perdana atas saham-saham yang diterbitkan oleh Emiten. Emiten wajib melaksanakan penawaran umum paling lambat 2 (dua) hari kerja setelah Pernyataan Pendaftaran menjadi efektif. Untuk masa penawaran umum sesuai dengan peraturan Bapepam-LK (OJK) No. IX.A.2 adalah paling kurang 1 hari kerja dan paling lama 5 (lima) hari kerja. Masyarakat atau calon invesor yang berminat membeli saham akan mengisi formulir pesanan dan menyerahkan uangnya kepada agen penjual. Pembayaran atas pemesan efek dilunasi paling lambat pada saat dilakukanya penyerahan efek. Dalam hal jumlah permintaan melebihi jumlah efek yang ditawarkan, maka harus diadakan penjatahan sesuai dengan peraturan No. IX.A.7 yang merupakan lampiran dari keputusan ketua Bapepam-Lk (OJK) No. Kep691/BL/2011 tanggal 30 Desember 2011. Penjatahan wajib diselaikan paling lambat 2 (dua) hari kerja setalah berakhirnya masa Penawaran Umum. Penyerahan efek beserta bukti kepemilikanya wajib dilakukan kepada pembeli efek dalam Penawaran Umum paling lambat 2 (dua) hari kerja setelah tanggal penjatahaan

Dengan bukti surat Pernyataan pendaftaran efektif dari OJK dan Penjualan di pasar perdana telah selesai maka perusahaan baru bisa meminta persetujuan BEI untuk pencatatan saham dan memperdagangkan sahamnya di BEI. Emiten mencatatakan efeknya di BEI selambatlambatnya dalam waktu 1 (satu) hari setelah tanggal Penyerah Efek. Seluuh transaksi di bursa adalah transaksi tunai, yang harus dibuktikan dengan nota transaksi atau akta pemindahan hak yang ditandatangani oleh penjual dan pembeli atau kuasanya. Dengan berakhirnya pasar perdana dan saham telah dicatatkan di bursa, maka segera setelah itu dimulailah perdagangan efek di pasar sekunder.

\section{Tugas Notaris Setelah Go Public}

Setelah berakhirnya Pasar Perdana dan saham telah dicatatkan di BEI, pada pecatatan efek di bi bursa inilah yang disebut dengan tahapan dimana suatu efek dari perusahaan memasuki Pasar Sekunder. Emiten berdasarkan POJK Nomor 30 /POJK.04/2015, berkewajiban untuk menyampaikan laporan realisai penggunaan dan hasil penawaran umum kepada OJK. Laporan tersebut dibuat secara berkala setiap 6 (enam) bulan dengan tangal laporan 30 Juni dan 31 Desember. Jika terjadi perubahan penggunaan dana, emiten harus menyampaikan hal itu ke OJK. Dalam hal penyampaian laporan ke OJK menyangkut perubahan dana harus mendapatkan persetujuan dari RUPS untuk ini diperlukan Akta Perubahan Anggaran Dasar yang dibuat oleh Notaris.

Jadi tugas Notaris setelah go public adalah dalam hal memproses pengesahan dari perbuatan-perbuatan hukum dari perusahaan yang mengakibatkan terjadinya perubahan 
Anggaran Dasar yang memerlukan persetujuan RUPS dan melegitimasi perjanjian-perjanjian yang melibatkan perusahaan.

Perbuatan-perbuatan hukum itu antara lain adalah Corporate Action adalah tindakan atau aksi korporasi emiten (perusahan Go Publik) yang berpengaruh terhadap jumlah saham yang beredar maupun terhadap harga saham perusahaan yang bersangkutan di bursa. Keputusan corporate action perlu mendapat persetujuan terlebih dahulu dalam rapat umum, baik rapat umum pemegang saham (RUPS) ataupun Rapat Umum Pemegang Saham Luar Biasa (RUPSLB). Persetujuan pemegang saham mutlak untuk berlakunya suatu corporate action sesuai dengan peraturan Pasar Modal.

\section{Tanggung Jawab Notaris Terhadap Akta-Akta Yang Dibuatnya Dalam Rangka Penawaran Umum (Go Public).}

Notaris selaku profesi penunjang yang membantu emiten dalam proses untuk go public, berdasarkan yang telah penulis uraikan diatas bahwa Notaris haruslah terdaftar terlebih dahulu di OJK, dan setelah terdaftar Notaris wajib untuk mengikuti pendidikan dan pelatihan yang diadakan oleh OJK, hal ini bertujuan agar Notaris mengetahui tentang ruang lingkup dari kegiatan yang akan dilakukannya, sehingga Notaris benar-benar mengetahui segala ketentuanketentuan yang mengaturnya dan dalam menjalankan tugas dan kewajibanya terutama dalam membantu peseroan untuk go public haruslah bertindak mandiri, jujur, tidak memihak dan penuh rasa tanggung jawab serta memberikan pelayanan yang profesional guna mengantisipasi pelangaran-pelanggaran yang mengakibatkan kerugian bagi perusahaan dan investor.

Tanggung jawab Notaris terhadap akta yang dibuatnya pada proses go public terjadi dalam hubunganya dengan pelaksanaan tugas dan kewajiban yang dibebankan Notaris berdasarkan kewenangan yang diberikan UUJN. Dengan kata lain pengaturan Notaris mengenai pembuatan akta otentik dalam proses penawaran umum tersebut harus sesuai sebagaimana yang diatur dalam UUJN. Berkaitan dengan substansi yang akan disepakati dalam akta tersebut melakat peraturan di bidang pasar modal seperti UUPM, OJK dan pelaksana lainya. Notaris bertanggung jawab terhadap akta yang dibuatnya, baik berupa partij akta maupun relaas akta.

Patij akta yaitu Notaris memuat apa yang di perjanjikan dan ditentukan oleh para pihak, contohnya akta perjanjian perjanjian emisi efek dan pengelolaan adminitrasi saham. Sedangkan akta relaas ialah Notaris membuat akta berdasarkan apa yang dialami dan disaksikan oleh Notaris sebagai pejabat umum contohnya Berita Acara RUPS. Dengan adanya dua macam sifat akta Notaris tersebut maka didalam prakteknya cara dan sistim pembuatanya pun berbeda. Didalam Partij akta, Notaris membuat berdasarkan keterangan atau hal-hal yang di inginkan para pihak, sedangkan di dalam akta relaas Notaris harus mengetahui dan menyaksikan sendiri perbuatan hukum yang terjadi yang mana akan dituangkan dalam suatu akta.

Oleh karena sifatnya berbeda maka pertanggung jawaban terhadap akta itupun berbeda, misalkan berita acara RUPS yang merupakan akta relas, jika isi akta tersebut terdapat kepalsuan atau kecurangan maka Notaris dapat diminta pertanggung jawabanya atas akta tersebut karena merupakan akta pejabat, begitu juga dengan akibat hukumnya jika salah satu tidak 
menandatangani maka akta tersebut tetap berlaku sebagai pembuktian yang sah tetapi Notaris harus menyatakan didalam akta tersebut alasan salah satu pihak tidak menanda tangani akta, sedangkan dalam partij akta Notaris membuat berdasarkan keterangan para pihak disertai dengan bukti dokumen formal maka jika didalam isi akta apabila terdapat keterangan yang tidak benar atau adanya itikad tidak baik, maka Notaris tidak bertanggung jawab terhadap akta para pihak tersebut untuk akibat hukumnya didalam partij akta jika salah satu pihak tidak menandatangani akta dianggap tidak menyetujui terhadap isi akta tersebut.

Didalam Pasal 80 ayat 1 UUPM dinyatakan bahwa : Jika Pernyataan Pendaftaran dalam rangka Penawaran Umum memuat informasi yang tidak benar tentang Fakta Material atau tidak memuat informasi tentang Fakta Material sesuai dengan ketentuan Undang-undang ini dan atau peraturan pelaksanaannya sehingga informasi dimaksud menyesatkan, maka setiap Pihak yang menandatangani Pernyataan Pendaftaran direktur dan komisaris Emiten pada waktu Pernyataan Pendaftaran menjadi efektif Penjamin Pelaksana Emisi Efek dan Profesi Penunjang Pasar Modal atau Pihak lain yang memberikan pendapat atau keterangan dan atas persetujuannya dimuat dalam Pernyataan Pendaftaran wajib bertanggung jawab, baik sendiri-sendiri maupun bersamasama, atas kerugian yang timbul akibat perbuatan dimaksud.

Pasal 80 ayat 1 tersebut mengatur bahwa Notaris sebagai salah satu pihak profesi penunjang pasar modal, bertanggung jawab atas kebenaran materil dari akta yang dibuat. Jika melihat dari ketentuan tersebut maka disini Notaris haruslah meneliti dan bertanggung jawab terhadap akta yang dubuatnya baik itu akta relaas maupun akta partij. Para pihak di dalam memberi keterangan untuk penawaran umum harus memenuhi keterbukaan, oleh karena itu Notaris tidak hanya meminta keterangan yang cukup tetapi juga harus benar. Notaris dilarang membuat akta yang berdasarkan keterangan pihak, jika pihak didalam memberi keterangan salah, keterangan setengah benar atau keterangan yang tidak lengkap. Didalam praktek sulit untuk mengetahui apakah keterangan yang diberikan para pihak benar atau tidak. Untuk itulah Notaris harus mempersiapkan dengan benar aktanya antara lain dengan melakukan due diligence. Adapun bentuk due diligence yang dapat dilakukan Notaris terhadap pembuatan akta-akta penawaran umum adalah sebagai berikut:

1) Berita Acara Perubahan Anggaran Dasar.

2) RUPS dilakukan tanpa kehadiran Notaris, akta dalam bentuk Pernyataan Keputusan Rapat (PKR).

3) Perjanjian Emisi Efek

4) Perjanjian Pengelolaan Administrasi Saham

Berdasarkan hasil wawancara penulis dengan Notaris Sugih Haryati, SH, M.KN di jakarta, ia menyatakan didalam pembuatan akta penawaran umum, nantinya ia akan melakukan penelitian secara mendalam (due diligence), ia mengatakan bahwa ia menggunakan due diligence karena sangat penting dan membantu kerja seorang Notaris misalkan, didalam pembuatan perubahan Anggaran Dasar PT tertutup menjadi Terbuka, maka Notaris harus meneliti anggaran dasar perseroan tersebut, dengan cara mengurutkan peralihan-peralihan dari awal sampai akhir, jangan sampai ada pemegang saham yang sah tetapi tidak dicantumkan di dalam anggaran dasar 
atau sebaliknya pemegang saham yang telah menjual sahamnya dicatat dalam Anggaran Dasar. Dengan dilakukanya due diligence maka Notaris dapat bertindak sebaik-baiknya di dalam menjalankan tugasnya sehingga akta Notaris tersebut tidak menimbulkan masalah dikemudian hari, karena hal yang akan menimbulkan tanggung jawab bagi Notaris di dalam pembuatan akta jika, mencantumkan keterangan tidak benar sehingga menimbulkan salah tafsir atau kerugian bagi para pihak atau pihak yang berkepentingan.

Apabila Notaris telah melakukan due diligence terhadap hal-hal tersebut diatas dan telah bekerja secara profesional maka, Notaris tidaklah dapat dimintakan pertanggung jawaban baik itu mengenai kebenaran formil maupun kebenaran materil dari akta-akta yang dibuat oleh Notaris. Notaris dapat menjalankan hak ingkar nya berdasarkan penjelasan di dalam Pasal 80 ayat (2) dan ayat (3) UUPM. Dalam ayat (2) disebutkan tangung jawab masing-masing profesi penunjang Pasar Modal (dalam hal ini Notaris) terbatas pada pendapat atau keterangan yang diberikannya dalam rangka pernyataan pendaftaran. Selanjutnya dalam ayat (3) disebutkan penjamin pelaksana efek atau profesi penunjang pasar modal (dalam hal ini Notaris) tidak dapat dituntut ganti rugi atas kerugian yang diderita oleh pemodal apabila telah melakukan penilaian atau memberikan pendapatnya secara profesional, dalam arti pekerjaanya telah dilaksanakan sesuai dengan norma pemeriksaan, prinsip-prinsip dan kode etik masing-masing profesi, dan pendapatnya atau penilaianya itu telah diberikan secara independen. Selain itu pelaksana emisi Efek atau profesi penunjang pasar modal telah melakukan langkah-langkah konkret yang diperlukan untuk memastikan kebenaran dari pernyataan atau keterangan yang diungkapkan dalam pernyataan pendaftaran (due diligence).

Tetapi hak ingkar Notaris tersebut tidaklah besifat mutlak, karena apabila Notaris terbukti telah melakukan kesalahan dan/atau perbuatan melawan hukum baik itu disengaja ataupun disebabkan oleh kelalaian Notaris sendiri maka, Para pihak yang dirugikan Notaris dapat menuntut ganti rugi, tetapi hanya dapat diajukan sampai jangka watu 5 (lima) tahun (pasal 80 ayat 4 UUPM). Selain sanksi perdata ada juga sanksi pidana dicantumkan di dalam UUPM. Untuk Notaris yang melanggar ketentuan pendaftran yaitu pasal 103 dengan ancaman pidana penjara paling lama 5 (lima) tahun dan denda paling banyak Rp 5.000.000.000,00,- (lima milyar rupiah). Sedangkan sanksi pidana bagi pihak yang memalsukan catatan/keterangan diatur di dalam pasal 107 dengan ancaman pidana paling lama 3 (tiga) tahun dan denda paling banyak Rp. 5.000.000.000,- (lima milyar rupiah).

Selain pengaturan oleh UUPM, OJK pun menghendaki setiap profesi bertanggung jawab terhadap kebenaran materil atau suatu pernyataan atau keterangan dalam rangka penawaran umum dengan membuat surat pernyataan yang merupakan dokumen yang harus ada pada saat menyampaikan pernyataan pendaftaran ke OJK. Surat pernyataan tersebut termuat dalam lampiran POJK Nomor 7/POJK.04/2017 tentang dokumen-dokumen pendaftaran dalam rangka penwaran efek bersifat ekuitas, efek bersifat utang, dan/ sukuk yaitu:

a. Kami bertanggung jawab bahwa segala sesuatu yang telah dilaksanakan dalam rangka penawaran umum adalah tidak bertentangan dengan peraturan jabatan notaris (Notaris Reglement) dan kode etik notaris; 
b. Kami sebagai profesi penunjang pasar modal dalam melaksanakan tugas telah bertindak sesuai dengan Notaris reglement serta kode etik notaris;

c. Kami sebagai profesi penunjang pasar modal dalam melaksanakan tugas bersikap indenpenden dan tidak memiliki benturan kepentingan dengan emiten;

d. Kami bertanggung jawab atas penelaahan dengan tugas dan jabatan dan telah mengajukan pertanyaan-pertanyaan dan permintaan informasi kepada emiten dan pihak lain yang dipandang perlu. Pertanyaan dan permintaan informasi tersebut mencakup seluruh informasi yang sesuai dengan notaris reglement, kode etik notaris dan peraturan pasar modal yang berlaku Setelah dilakukan penelaahan secara cermat dan seksama kami yakin bahwa pernyataan pendaftaran yang disampaikan sepanjang yang berhubungan dengan tugas dan jabatan kami tidak memuat pernyataan atau informasi yang tidak benar, sesuai dengan akta yang kami buat;

e. Setelah dilakukan penelaahan secara cermat dan seksama atas pernyataan pendaftaran sepanjang yang berhubungan dengan tugas dan jabatan kamus dan susai dengan Notaris reglement dan kode etik notaris, kami yakin bahwa tidak terdapat hal-hal yang dapat menghambat terlaksananya penawaran umum ini;

f. Kami bertanggung jawab atas pelaksanaan tugas dan jabatan kami dalam rangka penawaran umum ini dan kami juga telah membaca seluruh prospektus dan dokumen pernyataan sepanjang yang berhubungan dengan tugas dan jabatan kami terutama untuk melihat apakah informasi yang dimuat sesuai dengan akta-akta yang telah kami buat atau yang telah diperlihatkan kepada kami;

g. Dalam hal ditemukan adanya informasi yang tidak benar, menyesatkan atau belum mengungkapkan informasi yang seharusnya diungkapkan yang berhubungan dengan tugas dan jabatan kami,kami berjanji untuk segera menyampaikan informasi tersebut kepada OJK baik sebelum maupun sesuda pernyataan pendaftaran menjadi efektif dengan tidak mengurangi ketentuan hukum yang berlaku terhadap profesi kami mengenai rahasia jabatan.

Akibat hukum yang timbul dari tanggung jawab Notaris tersebut adanya sanksi yang diberikan oleh OJK dan organisasi ikatan Notaris indonesia (INI). Sebelum diberikanya sanksi maka OJK terlebih dahulu melakukan konsultasi kepada INI jika ada laporan yang ditemukan sendiri pelanggaran yang dilakukan Notaris. Dari laporan OJK tersebut kemudian INI melakukan pengawasan atas pelaksanaan kode etik. Pengawasan dilakukan oleh pengurus beserta Majelis Kehormatan. Jika pelanggaran dilakuakn di daerah maka yang bertindak pengurus daerah tetapi untuk tingkat pusat maka yang mengawasi adalah pengurus pusat. Dalam waktu selambatlambatnya 7 (tujuh) hari setelah laporan, Majelis Kehormatan Daerah (MKD) atau Majelis Kehormatan Pusat (MKP) mengadakan sidang untuk membicarakannya. Setelah sidang dilakukan, dalam waktu 7 (tujuh) hari dilakukan pemanggilan terhadap Notaris yang melakukan pelanggaran guna didengar keterangan dan pembelaaan dirinya. Setelah itu barulah diberikan keputusan selambat-lambatnya dalam waktu 15 (lima belas) hari setelah sidang. Apabila diputuskan ada pelanggaran maka hal tersebut dapat diberitahukan kepada OJK. 
OJK dapat memberikan sanksi administratif berupaPeringatan tertulis, Denda yaitu kewajiban membayar sejumlah uang tertentu, Pembatasan kegiatan usaha, Pembekuan kegiatan usaha, Pencabutan izin usaha, Pembatalan persetujuan; dan/atau, Pembatalan pendaftaran,

InI sendiri secara organisasi apabila ada anggota yang melanggar kode etik profesi dapat memberikan sanksi berupaTeguran; Peingatan;Schorsing; Pemecatan dari keanggotaan INI;

Jika ditinjau dari ketentuan UUJN, berkaitan dengan tanggung jawab Notaris terhadap akta yang dibuatnya, termuat dalam Pasal 65 UUJN yaitu Notaris, Notaris pengganti, dan pejabat sementara Notaris bertanggung jawab atas setiap akta yang dibuatnya meskipun prtokol Notaris telah dipindahkan ke pada pihak penyimpan protokol Notaris. Pertanggung jawaban dari Pasal 65 UUJN ini terjadi apabila terpenuhi unsur kesalahan (fault liability atau liability based on fault) yang merupakan prinsip yang cukup umum berlaku dalam hukum pidana dan perdata. Dalam KUH Perdata, khususnya pasal 1365, 1366, dan 1367, prinsip ini dipegang secara teguh. Prinsip ini menyatakan, seseorang baru dapat dimintakan pertanggungjawabannya secara hukum jika ada unsur kesalahan yang dilakukannya. Pasal 1365 KUH Perdata yang lazim dikenal sebagai pasal tentang perbuatan melawan hukum, mengharuskan terpenuhinya empat unsur pokok, yaitu: adanya perbuatan, adanya unsur kesalahan, adanya kerugian yang diderita, adanya hubungan kausalitas antara kesalahan dan kerugian.

Secara formil Notaris bertanggungjawab atas keabsahan akta otentik yang dibuatnya sebagaimana ditentukan dalam Pasal 84 UUJN. Notaris tidak bertanggung jawab atas kelalaian dan kesalahan isi akta yang dibuat di hadapannya, melainkan Notaris hanya bertanggung jawab bentuk formal akta otentik sesuai yang diisyaratkan oleh undang-undang. Sanksi atas kesalahan notaris dalam menjalankan jabatannya diatur dalam UUJN, yaitu Pasal 84 dan Pasal 85. Pasal 84 menentukan bahwa tindakan pelanggaran yang dilakukan oleh Notaris terhadap ketentuan sebagaimana dimaksud dalam Pasal 16 ayat (1) huruf i, Pasal 16 ayat (1) huruf k, Pasal 41, Pasal 44, Pasal 48, Pasal 49, Pasal 50, Pasal 51, atau Pasal 52 yang mengakibatkan suatu akta hanya mempunyai kekuatan pembuktian sebagai akta di bawah tangan atau suatu akta menjadi batal demi hukum dapat menjadi alasan bagi pihak yang menderita kerugian untuk menuntut penggantian biaya, ganti rugi, dan bunga kepada Notaris. Selanjutnya sanksi yang diatur dalam Pasal 85 berupa teguran lisan; teguran tertulis; pemberhentian sementara; pemberhentian dengan hormat; atau pemberhentian dengan tidak hormat.

\section{PENUTUP}

1. Perubahan Substansi Anggaran Dasar Perseroan Terbatas dalam Rangka Penawaran Umum (Go Public) Perseroan Terbatas yaitu:

Notaris yang akan melakukan kegiatan di pasar modal terutama dalam membantu perseroan dalam melakukan penawaran umum (go public) terlebih dahulu harus memperoleh izin dari Otoritas Jasa Keuangan (OJK). Ketentuan untuk Notaris yang berkegiatan di pasar modal diatur dalam Peraturan Otoritas Jasa Keuangan Nomor 67 /Pojk.04/2017 Tentang Notaris Yang Melakukan Kegiatan Di Pasar Modal (selanjutnya disebut POJK 67). Setelah OJK menetapkan Surat Tanda Terdaftar Profesi Penunjang Pasar modal (STTD) kepada 
Notaris, barulah Notaris dapat melakukan kegiatan di pasar modal. Perubahan subtasnsi anggaran dasar perseroan terbatas dalam rangka peawaran umum (go public) berdasarkan Undang-Undng Nomor 40 Tahun 2007 tentang Perseroan Terbatas (selajutnya disebut UUPT) ditetapkan oleh Rapat Umum Pemegang Saham (RUPS) dan UUPT juga mewajibkan untuk perubahan anggaran Dasar dinyatakan dalam akta Notaris

a. Tugas Notaris pada saat melakukan persiapan Go Public. Pada tahap ini Notaris akan membantu emiten menstrukturisasi terkait dengan permodalan dan saham serta aset perusahaan, selanjutnya Notaris membantu emiten dalam RUPS yaitunya membuatkan berita acar mengenai persetujuan untuk go public dan sekligus merubah anggaran dasar untuk disesuaikan dengan Keputusan Ketua Badan Pengawas Pasar Modal Nomor KEP179/BL/2008 tanggal 14 Mei 2008 tentang Pokok- Pokok Anggaran Dasar Perseroan Yang Melakukan Penawaran Umum Efek Bersifat Ekuitas dan Perusahaan Publik dan Notaris juga akan membuatkan akta perjanjian antara emiten dengan penjamin emisi, dan perjanjian pengeloalaan saham dengan Badan Adminitasi Efek (BAE).

b. Tugas Notaris pada proses penawaran umum (go public), tugas notaris disini pada umumnya hanyalah berkaitan dengan perubahan/adendum perjanjian emisi efek dan perjanjian pengeloalaan saham.

c. Tugas Notaris setelah penawaran umum (go public),yaitu dalam hal memproses pengesahan dari perbuatan-perbuatan hukum dari perusahaan yang mengakibatkan terjadinya perubahan Anggaran Dasar yang memerlukan persetujuan RUPS dan melegitimasi perjanjian-perjanjian yang melibatkan perusahaan.

2. Tanggung jawab Notaris terhadap akta yang dibuatnya dalam rangka penawaran umum (Go Public) adalah hanya sebatas keterangan-keterangan yang diberikan dan/atau yang diungkapkan oleh para pihak di dalam akta-akta yang dibuat. Notaris tidak bertanggung jawab terhadap kebenaran materil akta-akta tersebut, Notaris hanya bertanggung jawab atas kebenaran Formil. Namun Notaris harus penelitian mendalam (due diligence) terhadap keterangan- keterangan yang diberikan oleh para pihak. Notaris tidak bertanggung jawab terhadap kebenaran materil.

\section{DAFTAR PUSTAKA}

Ana Rokhmatussa'dyah dan Suratman, 2015, Hukum Investasi dan Pasar Modal, jakarta: Sinar Grafika;

Frenadin Adegustara, 2005, Hukum Administrasi Negara, Buku Ajar, Padang: Universitas Andalas;

G.H.S. Lumban Tobing, 1996, Peraturan Jabatan Notaris, Jakarta: Penerbit Erlangga;

Gunawan widjaja dan wulandari risnamanitis D, 2009, Go Public dan Go Private di Indonesia ( Seri Pengetahuan Pasar Modal), Jakarta : Kencana Prenada Media Grup;

Hamud M. Balfas, 2006, Hukum Pasar Modal Indonesia, jakarta : Tatanusa;

I Putu Gede Ary Suta, 2000, Menuju Pasar Modal modern, Jakarta: Yayasan Sa Satria Bhakti; 
Indroharto, usaha Memahami Undang-Undang Tentang Peradilan Tata Uasaha Negara, Beberapa Pngertian Dasar Hukum Tata Usaha Negara, Buku I, Jakarta: Pustaka Sinar Harapan;

Koesnadi Hardjasoemantri, 1988, Hukum Tata Lingkungan, Yogyakarta: Gajah Mada University Press;

Munir Fuady, 1999, Hukum Kontrak Dari Sudut Pandang Hukum Bisnis, Bandung, Citra Aditya Bakti;

M.Irsan Nasarudin dan Indra Surya, 2004 Aspek Hukum Pasar Modal Indonesia, Ed. 1, Cet. 3, Jakarta: Kencana Prenada Media Group;

Peter Mahmud Marzuki, 2009, Pengantar Ilmu Hukum, Cetakan Kedua, Kencana Prenada Media Group.

Phillipus M. Hadjon, 1986, Makalah Tentang Wewenang, Surabaya: Universitas Airlangga;

Saleh Basir dan Hendy M. Fakhrudin, 2005, Aksi Korporasi ( strategi untuk meningkatakan nilai saham melalui aksi korporasi), Jakarta: Salemba Empat;

Salim, HS, 2010, Perkembangan Teori Dalam Ilmu Hukum, Rajawali Pers, Jakarta;

Salim HS dan Erlies Septiana Nurbani, Penerapan Teori Hukum Pada Penelitian Disertasi dan Tesis, Buku Kedua, Jakarta: Rajawali Pres,

Tjiptono Darmadji dan Hendy M. Fakhruddin, 2001, Pasar Modal Di Indonesia ( Pendekatan Tanya Jawab), Jakarta : Salemba Empat. 